występowało wśród organizacji zajmujących się pomocą potrzebującym oraz charakterystycznymi dla Ziemi Wileńskiej problemami politycznymi i narodowościowymi. Trzeba podkreślić duży nakład pracy Autorki w uporządkowanie materiału - zaprezentowanie zawartości zasobów archiwalnych oraz wielu czasopism, dzięki którym jest możliwa rekonstrukcja jakże chlubnych działań polskich filantropów. Warto również oczekiwać kolejnych publikacji dotyczących organizacji dobroczynnych, które często mimo wielu lat swojej działalności, nie zostały jeszcze ujęte w opracowaniach historycznych.

Mikołaj Brenk

\title{
Szkolnictwo pijarskie w czasach minionych a wspólczesne proble- my edukacji historycznej, pod red. Krystynu Wróbel-Lipowej i Mariusza Ausza, Wydawnictwo eSPe, t.1, Kraków-Lublin 2010, sS. 215
}

450 rocznica urodzin św. Józefa Kalasancjusza i ogłoszenie roku 2007 pod patronatem tego Świętego przez ówczesnego ministra oświaty stała się przyczyną przypomnienia, przez wielu badaczy i na organizowanych przez nich konferencjach, postaci tego zakonnika i wychowawcy, a zarazem zakonu, który reprezentował - pijarów. Wcześniejszą publikacją, którą fetowano tę rocznicę była praca: Św. Józef Kalasancjusz 1557-1648. Życie oddane wychowaniu. Jubileusz 450. rocznicy urodzin Założyciela pijarów (Wydawnictwo Polskiej Prowincji Zakonu Pijarów, Kraków 2008, ss. 93), która stanowiła pokłosie sesji popularnonaukowej, 27 listopada 2007 r. w ramach uroczystości zamykającej obchody Roku Jubileuszowego św. Józefa Kalasancjusza w Polsce.

Nie inaczej jest $\mathrm{z}$ prezentowaną obecnie pracą - w ramach obchodów roku jubileuszowego Zakład Dydaktyki Historii Uniwersytetu Marii Curie-Skłodowskiej i Polska Prowincja Zakonu Pijarów zorganizowali międzynarodowa konferencję pt.: „Szkolnictwo pijarskie w czasach minionych a współczesne problemy edukacji historycznej”, która odbyła się w październiku 2007 roku w Kazimierzu Dolnym i Opolu Lubelskim. Omawiana publikacja, pod tym samym tytułem, jest pokłosiem obrad i jednocześnie zapowiedzią kolejnych tomów (ma być ich trzy).

Referenci poruszyli wiele interesujacych zagadnień dotyczacych historii zakonu, jego roli $w$ dziejach Polski - i nie tylko - oświaty oraz kultury - napisali we „Wstępie” redaktorzy tomu. Wszelkie rozważania, co zasługuje dziś na uwagę, prowadzono w kontekście współczesnych dylematów, przed którymi stoi dydaktyka historii. A tych nie brakuje...

Praca składa się z dwóch części - obie mają charakter historyczny. Pierwsza z nich, biograficzna, składa się ze „Wstępu”, „Przedmowy” i pięciu artykułów. Nosi ona tytuł: „Dwaj wielcy pijarzy Św. Józef Kalasancjusz i Stanisław Konarski”. Pierwszy z autorów, Eugeniusz Grzywacz (pijar), snuje rozważania na temat fenomenu szkolnictwa pijarskiego, które jest cenione od początków swojego istnienia, a zakłada się w prostej zasadzie wprowadzonej przez Kalasnacjusza: Pietas et Litterae, czyli Wiara i Wiedza. Niemożliwe 
jest bowiem rozwijać misji rozwoju intelektualnego bez należytej formacji duchowej. Kolejny autor jest także zakonnikiem - Edward Kryściak przedstawił postać Józefa Kalasancjusza i dzieło jego życia. Oba referaty mają, niestety, nieco homiletyczny charakter.

Postaci najbardziej znanego polskiego pijara, Stanisława Konarskiego, poświęcone są kolejne artykuły. Pierwszy z nich, autorstwa Czesława Nowarskiego, nosi tytuł: „Prognostyczność myśli ks. Stanisława Konarskiego w zakresie kształcenia i wychowania młodzieży". Autor nadaje bohaterowi swojego wystąpienia miano nauczyciela narodu, aczkolwiek nieco trafniej rolę tego pijara ocenił król Stanisław Poniatowski, nazywając go tym, który odważy się być mądrym. Opinia Czesława Nowarskiego podparta jest przede wszystkim publikacjami z prasy katolickiej i razi nieco jej hagiograficzny charakter.

Krystyna Wróbel-Lipowa jest kolejną autorką tej części tomu i opisuje największe osiągnięcie Stanisława Konarskiego - Collegium Nobilium, założoną przezeń szkołę patriotyzmu i wychowania obywatelskiego. Cenną cechą tej publikacji jest to, że jej Autorka postrzega ideę założenia Collegium na tle przemian edukacyjnych w Europie, a także analizuje sytuację, jaka istniała w II Rzeczypospolitej.

Pierwszą część tomu kończy publikacja Janusza Smykowskiego. Autor skupił się i przeanalizował „Program edukacyjny Stanisława Konarskiego w świetle współczesnych koncepcji edukacyjnych". Janusz Smykowski na początku sam zaznaczył, iż zamierza dokonać jedynie analizy tych treści teoretycznych, zawartych we współczesnej myśli pedagogicznej, które nie sa ściśle związane z przemianami technicznymi, kulturowymi czy wręcz cywilizacyjnymi, a które także dziś sa nadal przywoływane. Innymi słowy, autor stwierdził, że nie można porównywać celów, które przyświecały Konarskiemu w XVIII w., z tymi, które dzisiaj winien realizować system edukacyjny. Cenna uwaga.

Druga część publikacji przeznaczona została dziejom zakonu i szkolnictwa pijarskiego. Otwiera ją wspólny artykuł Krzysztofa Jakubiaka i Wiesława Jamrożka na temat historii wychowania jako przedmiotu kształcenia pedagogicznego w kontekście tradycji, teraźniejszości i przyszłości. Autorzy przyznają, że historia wychowania jest nauką dynamiczną i zmienną, aczkolwiek nie zawsze docenioną.

Kolejne rozważania, Romana Pelczara, zostały poświęcone szkolnictwu pijarskiemu na Rusi Czerwonej w XVII i XVIII w., a dokładniej ujmując, Autor koncentruje się na domach zachodnich w Chełmie, Lwowie, Rzeszowie, Warężu i Złoczowie. Posiadały one swoją specyfikę, która wynikała przede wszystkim z faktu bliskiego sąsiedztwa tych terenów z prawosławną Rosją i muzułmańską Turcją. To nakładało na zakon pijarski dodatkowe obowiązki i wyzwania, a także zaangażowanie w pracę na tych terenach najwybitniejszych zakonników, np. samego Konarskiego czy Onufrego Kopczyńskiego.

Tematykę terenów wschodnich kontynuuje w swoim artykule kolejny autor - Kazimierz Puchowski. Jego rozważania z kolei skupione zostały przede wszystkim na kształceniu elit w pijarskim Collegium Nobilium we Lwowie i wskazaniu głównych różnic między pijarami a najsłynniejszym zakonem nauczającym - jezuitami, którzy pomijali w swoim systemie wychowania edukację i służbę dla państwa. Należy jednak pamiętać, że Towarzystwo Jezusowe powstało w konkretnych realiach politycznych i przede wszystkim religijnych, skąd wynikał specyficzny ideał opisany w Ratio studiorum. Stąd, jak podaje Kazimierz Puchowski, właśnie z kręgów absolwentów pijar- 
skich wyszło wielu wybitnych działaczy z kręgów politycznych, gospodarczych, kulturalnych i naukowych.

Nad problematyką przeszłości w teatrze pijarskim w okresie staropolskim pochylił się Mariusz Brodnicki. Artykuł ma tę zaletę, że jego Autor pokazuje, jak wielką rolę w wychowaniu odgrywa współcześnie edukacja przez sztukę, bo to ona zajmuje coraz więcej miejsca w życiu człowieka. Tę prawdę znali już pijarzy i realizowali ideę wychowania przez sztukę z pełnym powodzeniem, po raz kolejny dystansując rywali - jezuitów - którzy co prawda także wystawiali przedstawienia, ale to właśnie pijarzy robili to po polsku.

Mariola Hoszowska przedstawiła postać innego pijara okresu Oświecenia. Mowa jest o Teodorze Wadze i jego koncepcji ideału kobiecości w Dziejach Polski, których był autorem. Ten podręcznik do nauczania historii wyróżniał się w epoce stanisławowskiej dużą ilością informacji poświęconym kobietom. Ale jak zaznaczyła Autorka artykułu, nie tyle jednak ilość miejsca, co charakter zamieszczonych informacji, pozwala określić Teodora Wage jako pisarza życzliwego kobietom, rzecznika ich aspiracji intelektualnych. Oczywiście na miarę epoki! Smutkiem napawa fakt, że współcześni autorzy podręczników historii często są bardziej zachowawczy i postaci kobiece są w ich narracji uwzględniane dużo rzadziej niż w pracy zakonnika!

O Litwie i stosunkach polsko-litewskich w myśli historycznej pijarów drugiej połowy XVIII w. traktuje artykuł Pawła Sierżęgi. Autor wskazuje na dużą rolę historyzmu epoki Oświecenia i jego znaczenia w kształtowaniu postaw obywatelskich i patriotycznych. Tym samym Paweł Sierżęga przypomina postaci pijarów historyków: wspomnianego wcześniej Teodora Wagę, Józefa Kajetana Skrzetuskiego i Bartłomieja Wincentego Skrzetuskiego.

Przy analizie i ocenie szkolnictwa pijarskiego zawsze istotne jest prześledzenie losów wychowanków pijarskich. To oni bowiem byli najlepszym potwierdzeniem zasadności istnienia szkół pijarskich i realizowania ich systemu wychowawczego. Obok szeregu postaci powszechnie znanych w polskiej historii, którzy byli uczniami pijarów, takich jak: Stanisław Małachowski, Ignacy Potocki, Stanisław Moniuszko, Joachim Lelewel, należy pamiętać o tych mniej popularnych. Do nich z całą pewnością można zaliczyć „ojca polskiej chirurgii" - Rafała Józefa Czerniakowskiego, pijara, ale także chirurga położnika i reformatora medycyny w Krakowie. Na jego biografii skupiła się Wioletta Malwa, kolejna współautorka tomu.

Równie ciekawy wątek rozważań zaproponowała kolejna uczestniczka konferencji Joanna Szady. Podkreślając na początku tekstu, że problem wykształcenia duchowieństwa w okresie staropolskim traktowany był w historiografii jednostronnie, Autorka postanowiła przeanalizować piśmiennictwo braci Zakonu Szkół Pobożnych w Polsce jako źródło do badań nad edukacją duchowieństwa końca XVIII w. w Polsce. Nie do końca jednak jestem w stanie zgodzić się z Joanną Szady, która uważa, że zasoby kościelnych zbiorów bibliotecznych są odbiciem kultury umysłowej ówczesnego duchowieństwa.

Ostatni artykuł tomu, autorstwa Jacka Chachaja, dotyczy wpływu szkół pijarskich na funkcjonowanie sieci szkół parafialnych na ziemiach ruskich Korony. Ma on nieco syntetyczny charakter i dobrze spina / puentuje wszystkie wcześniejsze rozważania na temat roli i znaczenia szkolnictwa pijarskiego na ziemiach polskich. Autor poprawnie definiuje 
terminy ,ziemie ruskie Korony”, ,szkoła parafialna” i finalnie pozostawia niedosyt czytelnikowi, który po lekturze nadal nie ma pewności czy pojawienie się na konkretnym terenie szkół zakonnych powodowało słabnięcie szkót parafialnych, czy też słabnięcie szkót parafialnych powodowało konieczność zakładania nowych szkół zakonnych. Być może jest to rzeczywiście problem nie do rozwiązania z racji niedostatku źródeł. Nie tłumaczy to jednak wykorzystywanie w tego typu publikacji przez Jacka Chachaja podręczników akademickich do nauczania historii wychowania (S. Kot, S. Litak).

$\mathrm{Z}$ całą pewnością publikacja warta jest lektury i poznania. Bo po pierwsze, jej istnienie przyczyni się do spopularyzowania wiedzy o polskich zakonach nauczających, do których najczęściej zalicza się jedynie jezuitów. Po wtóre zaś, doświadczenia pijarskie w zakresie nauczania być może wzbogacą współczesną edukację historyczną, gdzie nadal brakuje odpowiedzialności za młode pokolenia, które nie znają właściwego znaczenia takich pojęć jak: patriotyzm, obywatelskość i Ojczyzna.

Edyta Głowacka-Sobiech

\section{Bogusław Śliwerski, Przyrzeczenie Harcerskie. Historia. Metody- ka. Manipulacje, Wydawnictwo Impuls, Kraków 2009, ss. 244}

Zbliżająca się rocznica stulecia istnienia harcerstwa na ziemiach polskich jest doskonałą okazją, by przypomnieć, nie tylko samym harcerzom, czym ów ruch był w przeszłości dla Polaków, jakie funkcje społeczne spełniał, jakie ideały mu przyświecały, na czym polegała istota harcerskiej przygody.

Książką, która z pewnością przybliży czytelnikowi te i wiele innych kwestii związanych z harcerską służbą jest praca Bogusława Śliwerskiego zatytułowana: Przyrzeczenie Harcerskie. Historia. Metodyka. Manipulacje, wydana przez Wydawnictwo Impuls w 2009 r. Tematyka prezentowanej publikacji koncentruje się wokół tekstu harcerskiego przyrzeczenia, a ponieważ jest ono esencją ruchu, książka ta jest po prostu o harcerstwie.

Autorowi przyświecała bardzo szlachetna idea przy pisaniu tej książki. Założył bowiem we „Wstępie”, że każdy instruktor, by zrozumieć cechy i funkcje harcerskiego przyrzeczenia, powinien przede wszystkim poznać jego dzieje, by pogłębić swojá świadomość historyczna z korzyścia dla petnienia harcerskiej służby. B. Śliwerski przypomina także spór instruktorski z lat 1980-1981, który wywołany był co prawda sytuacją polityczną, ale przy okazji ukazał z całą bezwzględnością nieznajomość dziejów harcerskich wśród kadry. Poza tym, co szczególnie było gorącym tematem wśród harcerzy po 1989 r., to spory o rodowód harcerstwa, o prawo do używania harcerskich symboli, a także o to, kto tak w rzeczywistości jest prawdziwym harcerzem. B. Śliwerski przy rozwiązywaniu tego typu sporów poleca sięganie do przeszłości i właśnie w niej szukanie nie tylko skautowej tożsamości, ale i odpowiedzi na liczne pytania. Jego intencje nabierają większej wiarygodności, gdy dowiadujemy się, że prezentowana publikacja pisana była przed 1989 r., $w$ okresie restrykcyjnej cenzury i totalitarnych ograniczeń. 